www.jmscr.igmpublication.org

Impact Factor 5.84

Index Copernicus Value: 71.58

ISSN (e)-2347-176x ISSN (p) 2455-0450

crossref DOI: _https://dx.doi.org/10.18535/jmscr/v5i9.04

Journal Of Medical Science And Clinical Research

\title{
A Prospective Study of Clinical, Functional and Radiological Outcome in Unstable and Intra Articular Distal Radius Fracture Using Plates
}

Authors

\section{S.Alfred Sathiya Sekar ${ }^{1}$, A.M. Mohammed Zubair ${ }^{2}$, Dr Noorul Ameen ${ }^{3}$, M.Akela ${ }^{4}$}

${ }^{1}$ Senior Assistant Professor, Department of Orthopaedics, Kanyakumari Government Medical College ${ }^{2}$ Senior Assistant Professor, Department of orthopaedics, Kanyakumari Government Medical College

${ }^{3}$ Post Graduate, Department of Orthopaedics, Kanyakumari Government Medical College ${ }^{3}$ Intern, Kanyakumari Government Medical College

ABSTRACT
Background: The aim of study is to evaluate the clinical, functional and radiological outcome in unstable and intra
articular distal radius fracture using low profile plates in the department of Orthopaedics, KGMCH, Asaripallam
over a period of one year from Jan 2016 - Dec 2016.
Materials and Methods: This is a prospective study of 20 cases of unstable and intra articular distal radius fracture
treated by low profile plating.
Results: The unstable and intra articular distal radius fracture occurs commonly among males in RTA usually on
right side. Plating results in good anatomical restoration and early regaining of lost function.
Conclusion: The Intra articular distal radius fractures is a common fracture with increased incidence in road traffic
accidents among young patients, more common on right side. Restoration and maintaining of normal anatomy and
congruence using plate resulted in accelerated recovery and early return to the work.

\section{INTRODUCTION}

Fracture of distal radius is the most common fractures which represent $3 \%$ of all upper extremity injuries. Conservatively managed intra articular fracture often goes for malunion and stiffness consequently ending in delayed recovery and loss of function. This makes it necessary for anatomical restoration of distal radius fractures by operative treatment.

The internal fixation techniques is to enable osteo synthesis of individual fracture fragments of unstable distal radius and intra articular fractures that uses low profile plates to rigidly stabilise each fragment.

\section{ADVANTAGE}

To restore and maintain normal anatomy, for immediate joint mobilisation and accelerated recovery time.

\section{MATERIALS}

Twenty patients were randomly selected from the admissions in the accident and emergency ward in department of Orthopaedics, $\mathrm{KGMCH}$, and Asaripallam and recruited into the study prospectively based on the following criteria.

\section{INCLUSION CRITERIA}

- Age above 20 years

- Closed unstable distal radius fractures

- Closed intra articular distal radius fractures

\section{EXCLUSION CRITERIA}

- Age less than 20 years

- Compound fractures

- Old fracture more than 14 days

- Infection of fracture site

- Other fracture associated with same limb 
- Patients with co-morbid medical conditions

\section{PROCEDURE}

\section{APPROACHES AND TECHNIQUES}

The approaches to address the fracture fragment need to determine in pre-op planning. Volar approach used to assess volar lip or volar rim fragment.

\section{VOLAR APPROACH}

The skin incision at distal pole of scaphoid towards the radial border of flexor wrist crease, then extend proximally along FCR tendon. Open FCR tendon sheath and continue in the plane between FCR tendon and radial artery. Bluntly dissect along the surface of pronator quadratus and elicit some radial and distal attachment and reflect to ulnar side, also limit distal dissection no more than $1-2 \mathrm{~mm}$ beyond distal radial ridge.

\section{Technique}

Patient in supine position with arm extended in arm table under supraclavicular block. The affected limb is painted and draped. The incision is made over the sides of wrist as planned earlier. The fracture fragment is reduced by traction.

For the intra articular fragment, the comminuted dorsal cortical wall can be lifted using an elevator, disimpact the articular fragment, elevate the articular surface enblock. The volar fracture fragment is reduced by applying the dorsally directed force with an awl or periosteal elevator.

The articular congruity is restored by perfect reduction of fragments temporarily fixed with $1.2 \mathrm{~mm} \mathrm{~K}$-wire. The appropriate low profile fragment specific plate to stabilize the reduced fragment is selected corresponding to the wall, column and side to be fixed. The plate is secured proximally with cortical screws.

\section{Follow up}

All the patients were followed carefully, evaluating for any complications. After good union the patient were reviewed at $12^{\text {th }}$ week, evaluating the outcome based on Mayo Wrist Scoring system.

\section{CASE 1}

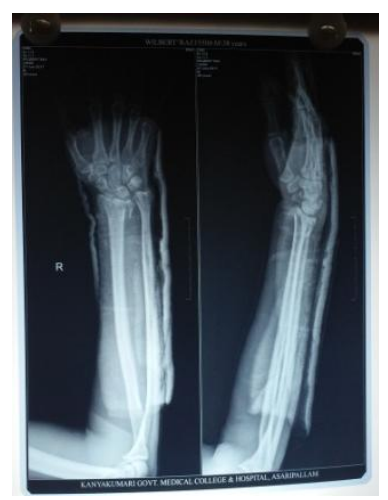

Pre-Operative

CASE 2

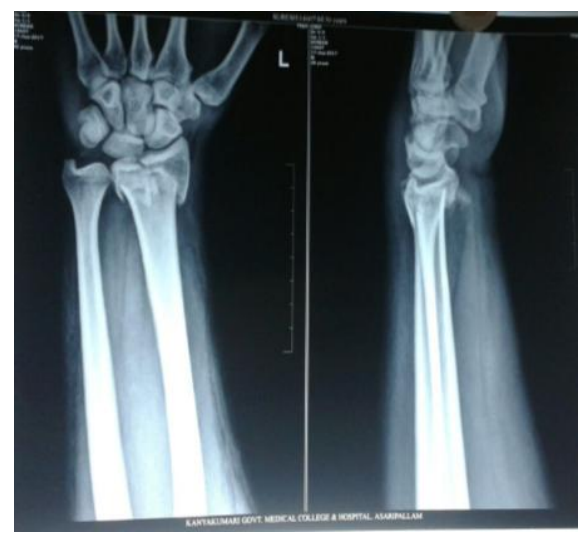

Pre-Operative

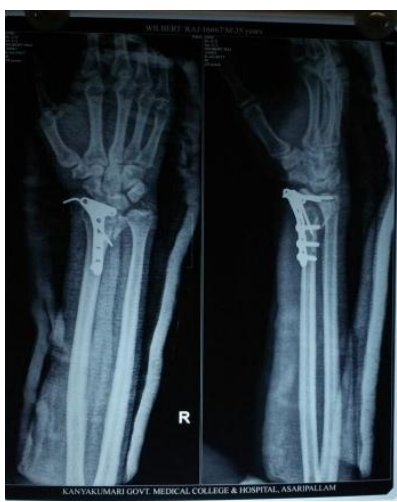

Post-Operative

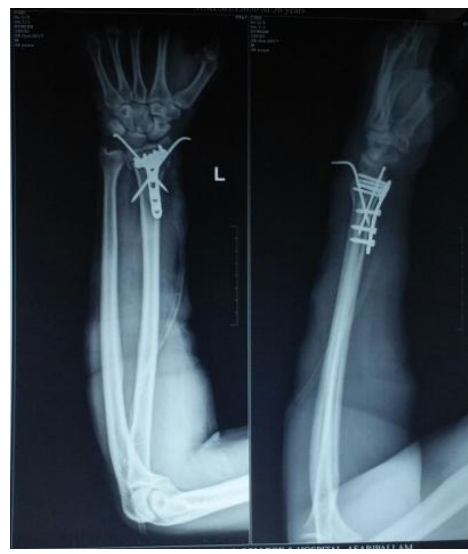

Post-Operative 
CASE 3

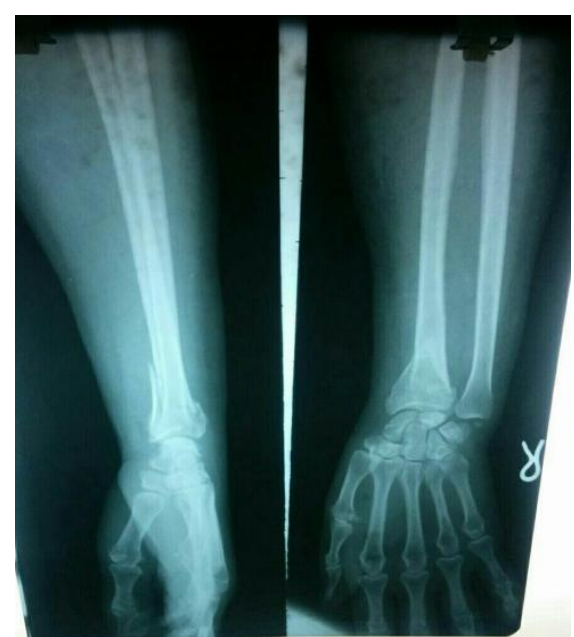

Pre-Operative

CASE 4

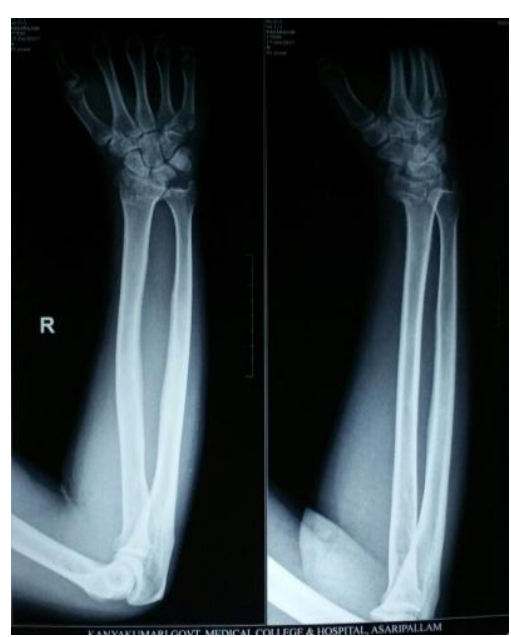

Pre-Operative

\section{RESULTS AND ANALYSIS}

\section{AGE DISTRIBUTION}

\begin{tabular}{|l|c|c|}
\hline Age Group & No. of cases & Percentage \\
\hline $20-30$ & 7 & 35 \\
\hline $31-40$ & 5 & 20 \\
\hline $41-50$ & 8 & 35 \\
\hline $51-60$ & 2 & 10 \\
\hline
\end{tabular}

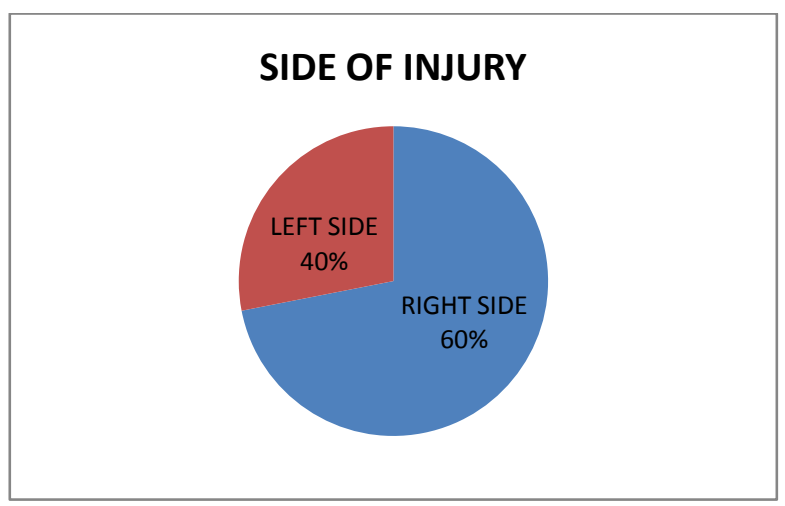

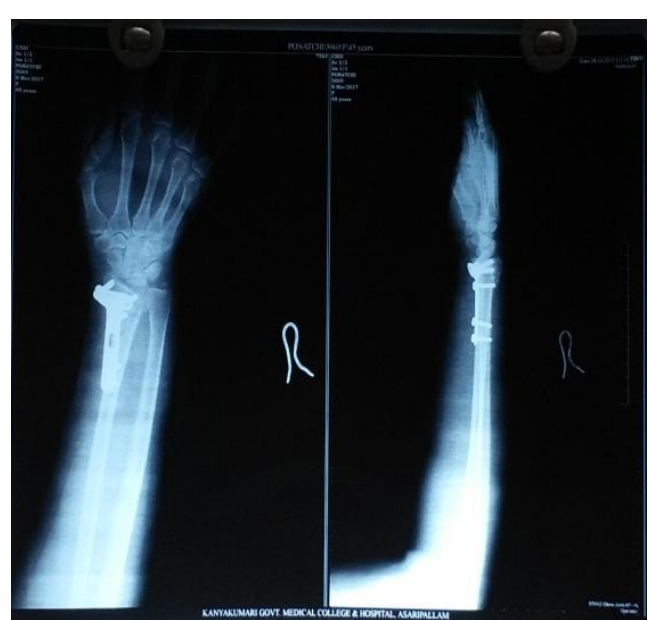

Post-Operative

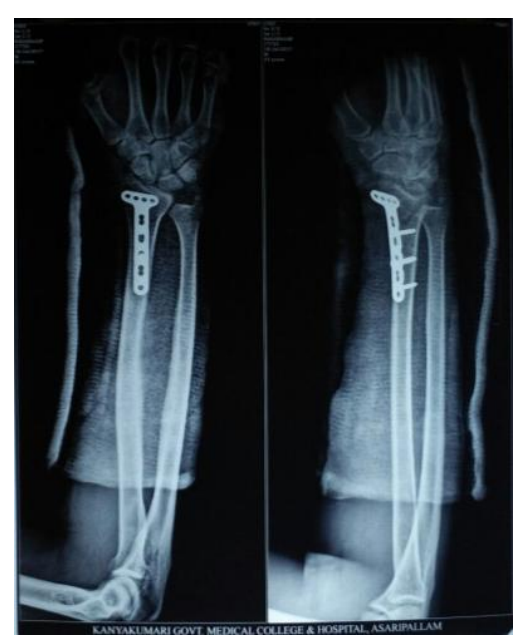

Post-Operative

Mode of injury

\begin{tabular}{|l|c|c|}
\hline MODE OF INJURY & NO. OF CASES & PERCENTAGE \\
\hline RTA & 11 & 60 \\
\hline Fall & 9 & 40 \\
\hline
\end{tabular}

Time interval between injury and surgery

\begin{tabular}{ccc}
\hline Time interval(Days) & No. of cases & Percentage \\
\hline$<2$ & 6 & 20 \\
$3-5$ & 8 & 50 \\
$6-14$ & 6 & 30 \\
\hline
\end{tabular}

\section{ASSOCIATED INJURIES}

Head injury $\quad: 1$

Spine injury $\quad: 1$

Orbit wall fracture $: 1$

Ankle sprain $\quad: 1$

Knee contusion $\quad: 1$ 


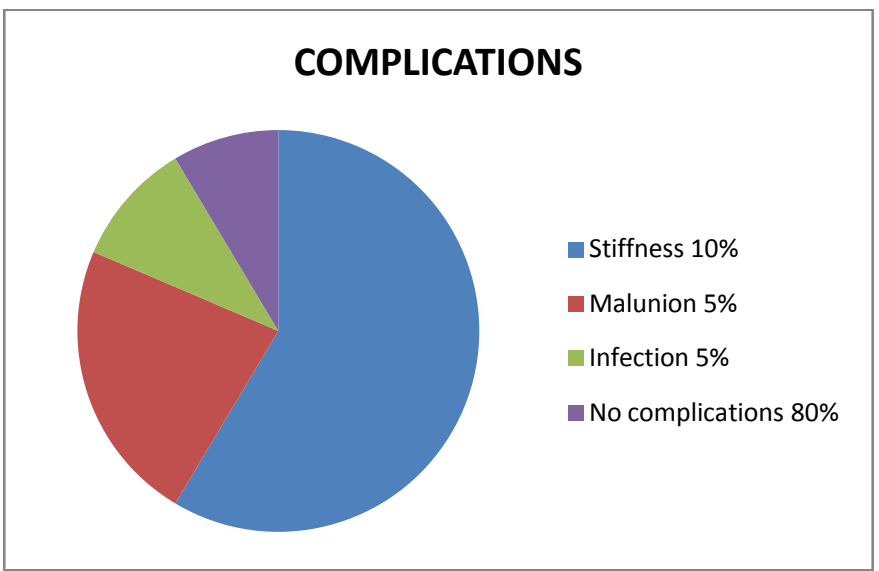

\section{FUNCTIONAL SCORE}

\begin{tabular}{|l|c|c|c|}
\hline $\begin{array}{l}\text { Mayo } \\
\text { score }\end{array}$ & Results & $\begin{array}{c}\text { No of } \\
\text { cases }\end{array}$ & Percentage \\
\hline $90-100$ & Excellent & 11 & 55 \\
\hline $80-90$ & Good & 6 & 30 \\
\hline $60-80$ & Satisfactory & 3 & 15 \\
\hline
\end{tabular}

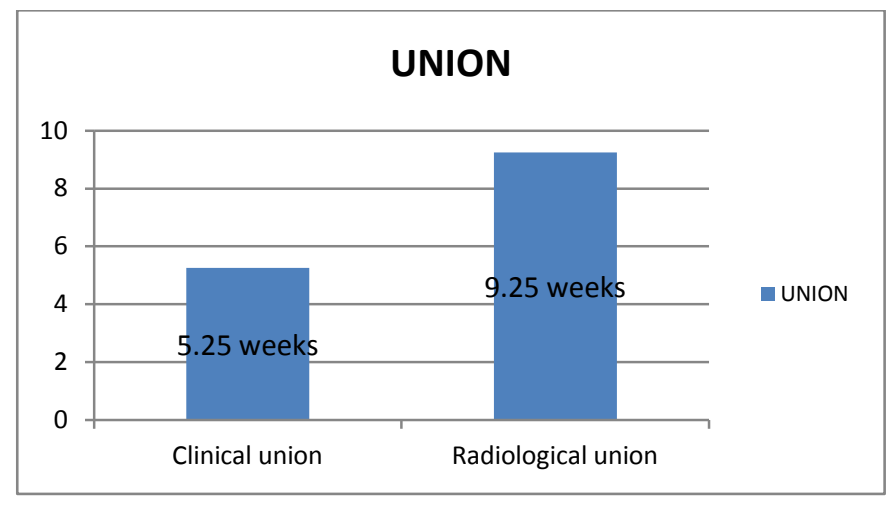

\section{CONCLUSION}

The distal radius fracture is a common fracture encountered in orthopaedic department. and intra articular fracture of distal radius .This is an unique approach to minimise soft tissue damage. Use of low profile plates with rounded and polished surfaces reduces soft tissue irritation. Plating results in stable and rigid fixation of each fragments individually and helps in immediate mobilisation of joints.

An adequate surgical technique will minimize complications and a personalised rehabilitation regimen will ensure best possible result .The surgeons familiarity with the approaches, technique and instruments also play an important role. Accurate anatomical reduction of the articular surface and stable fixation are mandatory for better functional outcome.

\section{REFERENCE}

1. Solgaard S, Petersen VS. Epidemiology of distal radius fractures. Acta Orthop Scand 1985; 56(5):391-393.

2. Lindau TR, Aspenberg P, Arner M, et al. Fractures of the distal forearm in young adults. An epidemiologic description of 341 patients. Acta Orthop Scand 1999; 70(2):124-128.

3. Cuenca J, Martinez AA, Herrera A, et al. The incidence of distal forearm fractures in Zaragoza. Chim Main2003;22(4):211-215.

4. Mallmin H, Ljunghall S, Persson I, et al. Risk factors for fractures of forearm: a population based case control study. Osteoporos Int 1994; 4(6):298-304.

5. Knirk J, Jupiter J. Intraarticular fractures of the distal end of the radius in young adults. J Bone Joint Surg 1986; 68(5):647659.

6. Solgaard S. Classification of distal radius fractures. Acta Orthop Scand 1984;56:249 -252 .

7. Batra s, Gupta A. The effect of fracturerelated factors on the functional outcome at 1 year in distal radius fractures. Injury 2002;33:499-502.

8. Solgaard S. Function after distal radius fracture. Acta orthop Scand1988;59(1):39-42.

9. Knirk JL,Jupiter JB. Intra -articular fractures of distal end of radius in young adults. J Bone Joint Surg Am 1986;68:647-659.

10. Trumble TE, Schmitt S, Vedder NB. Factors affecting functional outcome of displaced intra-articular distal radius fractures. J Hand Surg 1994;19:325-340.

11. Ruch DS, Ginn TA. Open reduction and internal fixation of distal radius fractures. Op Tech Ortho 2000;13:138-143.

12. Drobertz H, Kutscha-Lissberg E. Osteosynthesis of distal radius fractures with volar locking screw plate system. Int Orthop 2003;27(1):1-6. 